УДК 616-001/45-089:355.245

DOI 10.11603/2414-4533.2018.3.9447

\title{
(СО. ВРУБЛЕВСЬКИЙ
}

Лікарня Поморського медичного університету, щецин, Польща

"Лікарі без кордонів", Берлін, Німеччина

Emergency, Мілан, Італія

\section{Лікування бойової травми в циві.льного населення}

Дана праця спирається на особистий досвід автора під час гуманітарних місій та є спробою узагальнення результатів понад 1800 операцій, виконаних за останні три роки в “гарячих точках” світу.

XXI сторіччя, на жаль, не стало сторіччям миpy і спокою. Світом шириться хвиля воєн та тероризму (як індивідуального чи групового, так i державного). У даній ситуації при артилерійських обстрілах по жилих кварталах, неприцільній стрілянині з дрібної вогнепальної зброї, при підривах самогубців-смертників у людних місцях найбільше страждають діти, жінки, старші особи. Під час збройного конфлікту цивільне населення практично безахисне.

Власне допомогти цивільним жертвам воєнних конфліктів та терористичних нападів полягає головна мета так званої “воєнної хірургії” - не плутати з військовою - інша структура, хоча схеми лікування схожі. Зараз все частіше вживають термін “гуманітарна хірургія”, але це, на мою думку, більш узагальнююче поняття, яке включає хірургічну допомогу при різних гуманітарних катастрофах, не тільки під час збройних конфліктів. В 1971 р. група французьких лікарів створила міжнародну організацію “Лікарі без кордонів” (MSF Medecins sans Frontieres). MSF допомагає в усіх невідкладних ситуаціях - війни, збройні конфлікти, природні катаклізми, епідемії і працює в понад 80 країнах, особливо в країнах третього світу та країнах, огорнутих війною. В 2014-2015 рр. працювала місія MSF і на теренах окупованого Росією Донбасу, але окупанти змусили огранізацію згорнути свою роботу. В 1999 р. організація за свою діяльність була нагороджена Нобелевською премією Миру. Окрім MSF, активну гуманітарну працю проводять Міжнародна Організація Червоного Хреста, Emergency Italy, Aspen Medical, Міжнародний Медичний Корпус, Oxfam, та багато інших.

При роботі з бойовою травмою, перш за все, необхідно розуміти балістику в цілому та балістику рани зокрема. В дуже спрощеному вигляді це вигядає так - куля, яка вилітає зі ствола, не летить по абсолютно прямій лінії, вона обертається навколо власної осі, погойдується та відхиляється. При потраплянні в перешкоду - людське тіло, куля створює кульовий канал та дві порожнини постійну та тимчасову. За рахунок градієнта тиску туди засмоктуються різні сторонні тіла - шматочки одягу, бруду, землі тощо. Крім того, різний ступінь еластичності тканин тіла призводить до їх розтягування та стискання або ж до розриву та ламання. Тверді тканини такі, як кістки, можуть стати вторинними “снарядами”, які значно погіршують стан рани. Велике значення має кінетична енергія пошкоджувального снаряду, маса, кількість, краї (рвані рани гояться набагато гірше). Все це має вирішальний вплив на процеси лікування та загоєння бойових ран.

У структурі поранень спостерігається досить високий відсоток дитячого населення - від 1520 \% (Ємен, Демократична Республіка Конго, Афганістан) до 30-35 \% в Іраку та Нігерії. Серед дорослого населення близько 60 \% складають чоловіки, серед дітей різниці статі практично немає. Вік 8-12 років складає близько половини поранених дітей, молодші 8 р. -15 \%, старші 12 р. - 35 \%.

Структура поранень в основному залежить від типу зброї.

При застосуванні імпровізованих вибухових пристроїв [1-3] найбільше стражають кінцівки (до 30 \%) та численні рани всього тіла -до 80 \%.

Протипіхотні міни займають до 95 \% поранення нижніх кінцівок, проникаючі рани живота складают близько 35 \%, грудної клітини - біля $10 \%$ [4-6]. (В більшості випадків маємо справу 3 ураженнямі кількох ділянок тіла).

Вогнепальні кульові поранення в основному стосуються черевної та грудної порожнини - до 75 \%, кінцівки уражаються в 40 \%, голова -в 10 \%.

Відімо, що найчастіше уражається кишечник, печінка, сечоводи. При комбінованих торако-абдомінальних пораненнях - легені (потребують хірургічного лікування приблизно в 10-12 \%, достатньо введення двох (!) дренів до плевральної порожнини), діафрагма, печінка, селезінка, шлунок, поперечна ободова кишка. 
Опіки в основному як ураження співіснуюче при вибухах, рідко як ізольоване.

Для оптимального лікування в багатьох міжнародних організаціях, які працюють в зонах збройних конфліктів, створені на основі базових стандартів власні протоколи, які уніфікують та оптимізують надання медичної (хірургічної) допомоги. Це допомагає уникнути непорозумінь між лікарями з різних країн, які мають різний досвід і різні місцеві стандарти лікування.

У практиці хірурга при гуманітарній місії дуже часто трапляються випадки масового ураження. Такий стан оголошується, коли наплив пацієнтів (поранених) перевищує нормальні можливості прийому хворих за одиницю часу. Наприклад, госпіталь за добу може прийняти 120 пацієнтів, але коли така кількість прибуде протягом 20-30 хвилин (а така ситуація відбувалась досить часто), то оголошується план масового ураження (МСР - Mass Casualty Plan). Перший і основний момент - це медичне сортування, Triage. Система сортування, чи селекції поранених, вперше застосував Домінік Ж. Ларреєм під час наполеонівських воєн 1803-1815 рр. Це значно збільшило шанси поранених на виживання. Ця система, з певними модифікаціями, успішно використовується і на сьогодні.

Серед гуманітарних організацій однією 3 найбільш поширених є “START” - Simple Triage and Rapid Treatment. Теоретично це повинен проводити найбільш досвідчений лікар, що на практиці не завжди можливо. Відповідна селекція пацієнтів $€$ інтегральною частиною успішного хірургічного лікування. I часто є причиною морально-етичних вагань лікаря, бо часом відмовляєш у лікуванні пораненому, який ще живий, але ти розумієш, що прогноз pessima.

За роки праці в гуманітарних місіях вважаю найбільш доцільним 4-ступеневий алгоритм хірургічного лікування:

1. Селекція та реанімація

2. Хірургічний контроль пошкоджень (Damage Control Surgery)

3. Відновлення фізіологічних функцій

4. Дефінітивна хірургія.

Основним принципом у хірургічному лікуванні бойової травми, особливо при масовому надходженні поранених, є цілковитий приорітет рятуючих життя операцій - хірургічний контроль пошкоджень, контроль кровотечі, контроль інфікування, інтенсивне хірургіче очищення ран. Головним завданням на первинній стадії лікування $€$ розірвання смертельного трикутника:

1. Гіпотермія

2. Ацидоз

3. Коагулопатія
При виконанні хірургічного контролю пошкоджень звертаємо увагу, перш за все, на контроль кровотечі, запобігаємо подальшому інфікуванню та попереджаємо розвиток вторинної травми. Згідно з останніми рекомендаціями ATLS пацієнт потребує не більш як 1 л кристалоїдів перед операцією. Якщо мало, то переливаємо цільну кров, але не вводимо жодних колоїдних розчинів. Навіть найменшу операцію (якою вона видається на початку) необхідно виконувати тільки під загальним знеболенням. Якщо працюємо на черевній порожнині, то розтин повинен бути від кінця груднини до лона. Очищаємо черевну порожнину від згустків крові та вмісту - руками (!), пакуємо чотири великі абдомінальні хустки в усі чотири квадранти та додатково в мідницю. Після цього можна промити черевну порожнину фізіологічним розчином (3-5 л мінімум). Забираємо компреси починаючи 3 місця ймовірно меншої кровотечі. Контроль пошкодження печінки - застосовуємо мобілізацію правої печінкової з'язки, маневр Прінгля, прямий шов печінки. При обмеженні часу - утиск рукою, потім пакування абдомінальними хустками, краще між печінкою та діафрагмою i від черевної сторони. Таке подвійне пакування, на мою думку, є більш ефективним.

Окремо привертають увагу судинні пошкодження - все залежить від досвіду хірурга. Велика порожниста вена, якщо достатньо досвіду, накладається судинний шов (помітив таку особливість вен - рвуться вздовж осі, можуть виникнути труднощі при швах), немає досвіду - перев'язка вени. Загалом, в більшості випадків вени можна перев'язувати, а більшість артерій треба шити. При судинному дефекті найкраще застосувати графт із великої підшірної вени, якщо ж досвіду недостатньо, то як тимчасовий судинний стент застосовуємо назо-гастральний зонд відповідної товщини, який обов'язково промиваємо розчином гепарину. Таке застосування сприяє від 12 до 24 год до дефінітивної судинної операції. В приймальному відділенні можна використати кататер Фолея для тимчасової зупинки, особливо артеріальної кровотечі при кульових пораненнях стегна або шиї, вводячи його через вхідний отвір та помпуючи балон.

При пошкодженнях сечостатевої системи успішою $є$ надлонова цистостомія, використання double-J” стентів у сечоводах. Звичайно, пошкоджену нирку бажано зберегти, виконуючи часткові резекції. Те ж саме стосується і селезінки - при наявності вікрилових сіток або тканинних клеїв (у деяких госпіталях мали такі засоби) прагнули виконати органозберігаючі операції).

Для повного обстеження черевної порожнини та заочеревинного простору при операціях хірур- 
гічного контролю пошкоджень виконується право- або лівостороння вісцеральна ротація. Для запобігання інфекції, отвори в кишечнику можна позашивати (достатньо одношарового шва), якщо ж перфорацій багато - виконується разекція 3 простим зав’ язуванням кінців кишечника - комплексні резекції та анастомози відтерміновуєм до дефінітивної стадії. Також слід уникати ілео- або колостоми. По-перше, це затягує час операції, подруге, може спричинити вторинну контамінацію черевної порожнини у випадку нетримання швів. Черену порожнину замикаємо так, щоб уникнути синдрому стискання (Compartment syndrom). Найкраще застосувати Bogota bag.

Операції “second look" виконуються після 24 год (рідко), 48 год (оптимально), 72 год (відповідно до медичних показань) після первинної операції. Відстрочене первинне замикання рани [7-10] виконується на 4-6 добу, якщо немає ознак запалення. До цього часу рану не перев’язуємо!

\section{СПИСОК ЛІТЕРАТУРИ}

1. Giannou C. War surgery. Working with limited resources in armed conflict and other situations of violence / C. Giannou, M. Baldan. - Geneva, Switzerland : ICRC, 2010. - Vol. I. P. 358.

2. Giannou C. War surgery. Working with limited resources in armed conflict and other situations of violence / C. Giannou, M. Baldan, A. Molde. - Geneva, Switzerland : ICRC, 2013. Vol. 2. - P. 640.

3. Schein M. Schein's common sence Emergency abdominal Surgery (Sec. ed.) / Eds. M. Schein, P. Rogers, A. Assalia. Berlin Heidelberg : Springer-Verlag, 2005. - P. 650. DOI :10.1007/978-
На жаль, не всім пораненим вдавалося допогти. Рівень смертості був від 12-15 до 30 \%. На це впливає багато чинників - технічні можливості госпіталя, наявність відповідного персоналу, рівень країни (в одних країнах поранений доставлений до госпіталя через 1-3 год після поранення, в інших - навіть після кількох днів). I ще одне зауваження - навіть найкращий хірург найвищого рівня, але “мирного часу”, може завдати більше шкоди, ніж користі. I не тільки пораненим, але і собі. Оскільки наростаюча фрустрація результатами власної роботи: коли одного оперуєш, а п'ять інших помирає, а згодом і той перший помирає, і не розумієш, що діється і чому, призводять то тяжких депресивних станів.

Хірург повинен знати основи воєнної хірургії, бо це важливе при роботі з пораненими, особливо при масових поступленнях. На жаль, внаслідок воєн і тероризму - гинуть люди, а хірург повинен знати як правильно і ефективно допомогти в реаліях війни або терористичної загрози.

3-540-74821-2

4. Emergency War Surgery. Fourth United States Revision. USA : Department of Defence, 2013. - P. 476.

5. MSF Protocols and Gudelines. Revised Paris, 2015.

6. Emergency Protocols and Guidelines. Revised Milano, 2016.

7. WWAP. Guidelines for Afganistan. Geneva : ICRC, 2010.

8. ATLS, (X Edit.), ACSCT. Royal College of Surgeons of England, 2018. Retrieved from : https://goo.gl/OfBK07

9. ETC. Lisbon, Portugal, 2018.

10. Management of Limb Injuries during disasters and conflicts / ICRC, WHO, AO Foundation. Geneva, Switzerland : ICRC, 2016.

\section{REFERENCES}

1. Giannou, C. \& Baldan, M. (2010). War surgery. Working with limited resources in armed conflict and other situations of violence. Geneva, Switzerland: ICRC.

2. Giannou, C., Baldan, M. \& Molde, A. (2013). War surgery. Working with limited resources in armed conflict and other situations of violence. Geneva, Switzerland: ICRC.

2. Schein, M., Rogers, P. \& Assalia, A. (Eds.) (2005). Schein's common sence Emergency abdominal Surgery (Sec. ed.). Berlin Heidelberg: Springer-Verlag. DOI :10.1007/978-3-540-74821-2

3. (2013). Emergency War Surgery. Fourth United States
Revision. USA: Department of Defence.

4. (2015). MSF Protocols and Gudelines. Revised Paris.

5. (2016). Emergency Protocols and Guidelines. Revised Milano.

6. ICRC. (2010). WWAP. Guidelines for Afganistan. Geneva: ICRC.

7. Royal College of Surgeons of England (2018). ATLS, (X Edit.), ACSCT. Retrieved from: https://goo.gl/OfBK07

8. (2018). ETC, Lisbon, Portugal.

9. ICRC, WHO, AO Foundation. (2016). Management of Limb Injuries during disasters and conflicts. Geneva, Switzerland: ICRC. 
O. VRUBLEVSKYI

Hospital of Pomor Medical University, Szczecin, Poland

Doctors without Borders, Berlin, Germany

Emergency, Milan, Italy

\section{TREATMENT OF BATTLE TRAUMA IN CIVIL POPULATION}

This work is based on the own experience of the author during humanitarian missions and is an effort of generalization the results of more than 1800 surgeries performed for the last three years in hot spots of the world.

\section{А. ВРУБЛЕВСКИЙ}

Больница Поморского медицинского университета, Щецин, Польша

"Врачи без границ", Берлин, Германия

Emergency, Милан, Италия

\section{ЛЕЧЕНИЕ БОЕВОЙ ТРАВМЫ В ГРАЖДАНСКОГО НАСЕЛЕНИЯ}

Данная работа основывается на личном опыте автора во время гуманитарных миссий и является попыткой обобщения результатов более 1800 операций, выполненных за последние три года в “горячих точках” мира. 